Primljeno: 16.4.2018. Revidirana verzija: 23.5.2018. Odobreno za štampu: 5.6.2018. DOI: https://doi.org/10.46630/gped.1.2018.08

\title{
MEDIJI U PREDŠKOLSKOM OBRAZOVANJU
}

(Novi mediji u ranom obrazovanju autorki Stanisavljević Petrović, Z. i Pavlović, D., naučna monografija, Filozofski fakultet Niš, 2017, 220 strana)

\author{
Anastasija Mamutović ${ }^{11}$ \\ Univerzitet u Nišu, Filozofski fakultet u Nišu, Departman za pedagogiju
}

Monografija Novi mediji u ranom obrazovanju nastala je u okviru rada na projektu „Tradicija, modernizacija i nacionalni identiteti u Srbiji i na Balkanu u procesu evropskih integracija" (179074) koji realizuje Centar za sociološka istraživanja Filozofskog fakulteta u Nišu, uz podršku Ministarstva nauke, prosvete i tehnološkog razvoja.

Tema primene novih medija u ranom obrazovanju je posebno značajna na našim prostorima, gde još uvek nije došlo do adekvatnog pozicioniranja novih medija u procesu obrazovanja. Situacija se posebno usložnjava na nivou predškolskog vaspitanja i obrazovanja u kome egzistiraju brojni problemi poput materijalne opremljenosti, kompetentnosti vaspitača za primenu savremenih IKT, predrasude o odnosu dece predškolskog uzrasta i novih medija, kao i pitanja potencijala novih medijskih tehnologija u ranom obrazovanju i vaspitanju.

Autorke u monografiji pružaju osvrt na teorijska polazišta na kojima se zasniva primena novih medija u ranom obrazovanju, razmatraju mogućnosti za primenu medijskih alata u predškolstvu i navode iskustva dobre prakse implementacije medijskih tehnologija. U cilju modernizacije i unapređivanja vaspitno-obrazovnog rada autorke navode dragocene rezultate istraživanja koje je imalo za cilj utvrđivanje stavova vaspitača predškolskih ustanova na teritoriji Republike Srbije o primeni novih medijskih sredstava u predškolskim ustanovama. Knjiga sadrži sedam glavnih poglavlja u okviru kojih se definišu i predstavljaju novi mediji, analizira njihova uloga u transformaciji predškolskog obrazovanja, razmatra doprinos medijskih tehnologija dečijem razvoju i ukazuje na potrebu jačanja kompetencija vaspitača za primenu novih medija.

Svrha gorepomenutog dela je sveobuhvatno i analitičko prikazivanje savremenih digitalnih alata i ukazivanje na potencijale i benefite implementacije novih medija u vaspitno-obrazovni rad predškolskih ustanova. Posebno je naglašena potreba podizanja svesti svih aktera vaspitno-obrazovnog procesa u preuzimanju odgovornosti za kvalitet i inoviranje prakse.

\footnotetext{
${ }^{1}$ anastasija.mamutovic@filfak.ni.ac.rs
} 
Kako novi mediji predstavljaju kompleksan pojam, autorke navode nekoliko relevantnih određenja u cilju njegovog adekvatnijeg shvatanja i razumevanja. Zatim ukazuju na potrebu za transformacijom predškolskog obrazovanja i novim dizajniranjem vaspitno-obrazovnog rada uz primenu digitalnih alata. U monografiji se iznosi ideja o potrebi za većim udelom savremenih medijskih alata u predškolskom vaspitanju i obrazovanju. Navode se značajni razlozi za inoviranje vaspitno-obrazovne prakse, među kojima se izdvaja društveni kontekst sa svojim karakteristikama. Posebno se ističe potreba za većom informatičkom pismenošću, adekvatnim obrazovanjem i doškolovavanjem vaspitača za primenu medijskih alata. Fokus interesovanja nije usmeren samo ka jednostranom promovisanju isključivo medijskih tehnologija uz poricanje vrednosti tradicionalnih pristupa u radu, već autorke „otvorenog uma” pozivaju na uspostavljanje balansa između primene tradicionalnih aktivnosti i modernih medija, te navode da ovakav kombinovani pristup proizvodi u praksi najviše benefita za razvoj dece predškolskog uzrasta.

Među brojnim digitalnim medijima čiji se broj neprestano povećava veoma je teško izabrati one efikasne koji će doprineti razvoju dece predškolskog uzrasta. Monografija u tom pogledu predstavlja i vrstu putokaza vaspitnom kadru, budući da navodi kriterijume koji mogu pomoći u odabiru medijskih alata za primenu u vaspitno-obrazovnom radu, a među kojima se izdvajaju interaktivnost, aktivno pozicioniranje, uključenost i intervencija dece. Karakteristike i mogućnosti novih medijskih alata koji su predstavljeni u monografiji su opisani i kroz primere dobre prakse u svetu. U tom kontekstu, najpre su predstavljeni računari kao digitalni alati sa najširim spektrom moguće primene. Naglašava se da oni omogućavaju upotrebu raznih softvera koji mogu biti višestruko korisni za sve učesnike u procesu obrazovanja. Kada je reč o deci predškolskog uzrasta, računari omogućavaju pristup velikom broju edukativnih softvera, računarskih igara sa edukativnom vrednošću, elektronskih slikovnica i čitave plejade internet servisa sa ogromnim potencijalom za poboljšanje akademskih i socijalnih veština. Osim računara, autorke ističu potencijale interaktivne table, posebno ih potvrđujući predstavljanjem većeg broja istraživanja. Osim toga, pažnja je usmerena i ka mogućnostima i benefitima mobilnih uređaja i elektronskih edukativnih igračaka.

Pored toga što se ističe da novi mediji pružaju visoke mogućnosti za kreativno oblikovanje sadržaja vaspitno-obrazovnog rada koje će biti od koristi za decu i za vaspitače, u monografiji se navode i primeri dobre prakse u razvijenim zemljama u cilju implementacije istih u naš sistem predškolstva. Novi mediji se definišu kao moćni alati za učenje, istraživanje, razvijanje kreativnosti, ispoljavanje originalnih ideja i stručno usavršavanje vaspitača, pod uslovom da se koriste primereno razvojnim karakteristikama dece predškolskog uzrasta. Pozitivan uticaj novih medija na buđenje motivacije i novog doživljaja učenja koje je prožeto interesovanjem nalazi se u osnovi argumentacije autorki za pozivanje vaspitača na korišćenje medijskih sredstava koja su u vrtiću dostupna. Valjana potkrepljenost tvrdnji u monografiji ogleda se u činjenici da su navodi praćeni rezultatima relevantnih naučnih pedagoških, psiholoških i socioloških istraživanja. Kako se deca modernog doba još u porodičnom kontekstu upoznaju sa digitalnim okruženjem, prve navike u pogledu 
upotrebe novih medija (kako u kvantitativnom tako i u kvalitativnom smislu) nastaju upravo u porodici, a kasnije se u predškolskoj ustanovi teško naknadno menjaju. Iz tog razloga neophodno je razmotriti odnos dece i novih medijskih tehnologija, prevashodno zadatke vaspitača i roditelja u razvijanju medijskih kompetencija dece.

U tom pogledu, autorke nisu zaobišle ni sistematično promatranje postojećih kontroverzi vezanih za uticaj medija na rast, razvoj i napredovanje dece. Kako se pitanje odnosa dece i novih tehnologija karakteriše kompleksnošću, te uglavnom svodi na pitanje delovanja medijskih tehnologija na dečiji rast i razvoj, autorke izdvajaju tri značajna elementa: vrsta medija, vreme koje deca provode uz medije i karakteristike medijskih sadržaja. U monografiji se ukazuje na obrazovne efekte elektronskih slikovnica, interaktivnih tabli, mobilnih uređaja i elektronskih edukativnih igračaka i opravdano se kao suštinska karakakteristika medijskih tehnologija izdvaja interaktivnost.

U poglavlju pod nazivom „Vaspitači i novi mediji“ autorke polaze od stava da je primena novih medijskih tehnologija u vaspitno-obrazovnom radu predškolskih ustanova determinisana stavovima vaspitača, ali i njihovim digitalnim kompetencijama. U vreme kada je informatičko opismenjavanje podjednako važno kao i opšta pismenost, nema sumnje da su sadržaji vezani za oblast digitalnih kompetencija veoma važni i čine sastavni deo vaspitno-obrazovne prakse. Kako se deca još od najranijeg uzrasta u porodičnom okruženju upoznaju sa medijskim sredstvima, između ostalog i sa računarom, neophodno je taj proces nastaviti i u predškolskim ustanovama. Autorke ističu da je nesumnjivo uticaj novih tehnologija na decu predškolskog uzrasta prisutan i da posmatrano sa pedagoškog i psihološkog aspekta ima niz prednosti, ukoliko se u vaspitnom radu koristi kao dopunsko sredstvo, umereno i adekvatno. Međutim, potrebno je imati u vidu da nove tehnologije ne mogu u potpunosti zameniti manipulaciju predmetima i igračkama, komunikaciju dece i vaspitača, kao i fizičke aktivnosti na otvorenom prostoru.

Zasnovano na stavovima relevantnih istraživanja autorke argumentovano ukazuju na potrebu za sistemskim rešenjima u oblasti informatičkog obrazovanja vaspitača predškolskih ustanova, jer je bitan preduslov za uvođenje medijskih tehnologija u oblast predškolskog vaspitanja vezan za kompetencije vaspitača. U tom kontekstu autorke skreću pažnju na jedan od suštinskih problema koji predstavlja glavnu prepreku većoj primeni savremenih medijskih alata.

Značajna pažnja u monografiji posvećena je i saradnji sa roditeljima i lokalnom zajednicom, jer uvođenje novih medija u rad predškolskih ustanova otvara mogućnosti za inoviranje procesa saradnje. Korišćenje digitalnih kanala omogućuje brzu i konkretnu razmenu informacija, čineći da roditelj bude potpuno informisan o napredovanju deteta. U ovoj karakteristici autorke vide mogućnost postizanja vremenski efikasnije interakcije između vaspitača i roditelja kroz nove tehnologije. Osim toga, omogućava se i interakcija između predškolske ustanove i porodice, čime se taj odnos čini otvorenijim i transparentnijim i na taj način pozitivno utiče na roditeljske stavove pružajući im više mogućnosti da se uključe u vaspitanje deteta. Autorke smatraju da nove medijske tehnologije mogu imati značajnu ulogu u procesu otvaranja predškolske ustanove prema lokalnoj zajednici u cilju uspostavljanja 
funkcionalne saradnje. Za uspešno funkcionisanje predškolske ustanove neophodna je povezanost sa lokalnom sredinom u kojoj se nalazi. Lokalna zajednica svojim posrednim ili neposrednim delovanjem pruža podršku predškolskoj ustanovi u izvršavanju osnovne, ali i pratećih delatnosti i na taj način doprinosi realizaciji vaspitno-obrazovnih ciljeva i zadataka.

Istraživački deo monografije pruža osvrt na rezultate istraživanja koje je sprovedeno na uzorku od 465 vaspitača predškolskih ustanova sa ciljem da se ispitaju njihovi stavovi prema primeni medijskih sredstava u predškolskom obrazovanju. Rezultati istraživanja prikazani u knjizi pokazuju da je broj vaspitača koji koriste savremene medijske alate relativno mali, kao i da su tradicionalna medijska sredstva poput radija i TV-a i dalje dominantna u vaspitno-obrazovnom radu predškolskih ustanova. Kada je u pitanju domen rada vaspitača u kojem je medijska tehnologija najzastupljenjija, autorke dolaze do saznanja da je u pitanju preparativna etapa pripreme materijala za rad. Uprkos nedovoljnoj zastupljenosti novih medija u radu sa decom ranog uzrasta vaspitači koji su činili uzorak istraživanja pozitivno procenjuju sopstvene kompetencije za korišćenje medija kao što su Power Point, Word, e-mail i Excel. Autori knjige kao implikacije istraživanja koje su sprovele navode potrebu za većim posvećivanjem pažnje informatičkoj edukaciji vaspitača putem seminara i razmene informacija $\mathrm{i}$ iskustava sa kolegama, kao i potrebu za dodatnim opremanjem predškolskih ustanova medijskim sredstvima. Rezultati istraživanja mogu doprineti promenama u predškolskom obrazovanju u smislu implementacije savremenih digitalnih sredstava u vaspitno-obrazovni proces predškolskih ustanova.

Knjiga Novi mediji u ranom obrazovanju bavi se veoma aktuelnom tematikom pozicioniranjem modernih medijskih tehnologija u oblasti predškolskog vaspitanja i obrazovanja i namenjena je veoma širokoj čitalačkoj publici, a prevashodno akterima u vaspitno-obrazovnom radu. Sadržina dela sistematizovana je tako da omogući svim čitaocima najpre teorijska potkrepljenja primene modernih medijskih alata, a nakon toga se bavi refleksijom prakse iz pozicije vaspitača. Doprinos monografije ogleda se u činjenici da se autorke $u$ analizi tematike ne zaustavljaju isključivo na deskripciji prakse već predlažu brojna rešenja za uočene probleme, a među njima se posebno izdvaja potreba za sistemskim promenama u smislu adekvatnijeg opremanja predškolskih ustanova, ali i promena u sadržajima i strukturi programa za obrazovanje vaspitača. Stoga, predstavljena monografija predstavlja vredno delo i osnovu budućih istraživanja koja bi se fokusirala na transformaciju predškolskog obrazovanja kroz primenu savremenih digitalnih tehnologija. 